\title{
Industrial relations at Motonui - an examination of a successful industrial relations strategy on a large construction project
}

\author{
Peter Cammock*
}

This paper presents a description of industrial relations on the Motonui methanol plant project. In particular it examines the approach to industrial relations taken by the major contractor Bechtel (Pacific) Corporation Ltd. The paper argues that managerial practice can significantly increase industrial harmony even in industries with a predisposition to conflict. The case of the Motonui project is presented in support of this argument.

Research in New Zealand industries experiencing high levels of conflict indicates a perception by many managers that the conflict in which they are involved is caused by factors beyond their control. Inkson, in discussing management in the meat freezing industry, refers to a "kind of baffled abrogation of responsibility into managerial pessimism, fatalism and helpless inaction" (1980, p. 14). Such perspectives are reinforced by a media presentation of industrial conflict as something "caused" by militant trade unions and outside the control of managers (Hartman, 1976; Cordery et al., 1978; Cammock, 1982).

The academic literature has perhaps added to this perception by neglecting the role of managers in industrial relations. Textbooks which provide a detailed analysis of union and state institutions often ignore or treat superficially the behaviours and strategies of managers and employers (see for example, Howell et al. 1974; Jackson, 1978). Commenting on this neglect Clegg (1979, p. 164) concludes "The truth of the matter is that the study of management in industrial relations is in a primitive state"

Since Clegg's statement the role of managers in industrial relations has come under greater scrutiny (see for example Storey, 1983; Edwards and Scullion, 1982; Niland and Turner, 1985). However the study of management in industrial relations is still a relatively neglected area of research. This paper suggests with Inkson (1980) a relationship between levels of overt industrial conflict and the quality of management. It contends that managerial attitudes and practices can significantly increase industrial harmony even in industries that are heavily predisposed to conflict. Specifically it examines managerial practice on the Motonui methanol plant construction project ( $4 \mathrm{~km}$. east of Waitara on the Taranaki coast) and identifies aspects of managerial practice which have significantly reduced the incidence of overt industrial conflict on the project.

\section{Background}

Project construction, for a variety of reasons (for example, the nature of the work and the employment relationship) is an industry with a "predisposition toward conflict" (Turkington, 1976, p. 222). In his study of the industry Turkington noted however, that there were major variations between projects with some experiencing almost no stoppages at all. This variation can also be seen in the industrial relations records of the major construction projects carried out in New Zealand in the 1980s.

Compared with the other major projects, particularly the Marsden Point refinery expansion but also the New Zealand Steel Plant at Glenbrook and the Cromwell Dam, the Motonui

\footnotetext{
Lecturer in organisation behaviour and industrial relations, University of Canterbury.
} 
methanol plant project was highly successful. Bechtel Pacific Corporation Ltd, the major contractor, completed the project on time (opening February 1986) and about 20 percent under the budgeted costs of US\$1475 million. In particular, the project has been notable for its harmonious industrial relations, with lost time due to industrial conflict substantially lower than the trends set on the other major projects.

In contrast, the most comparable of the other projects, the Marsden Point expansion, was completed with massive cost and time overruns. Additional costs due to industrial disruption have been estimated to have been as high as $\$ 150$ million. The New Zealand Steel plant and the Cromwell Dam projects have also experienced a level and intensity of industrial conflict not approached at Motonui. Motonui's industrial relations record, particularly in comparison with other major projects makes it a worthwhile area of study. This paper does not attempt a detailed analysis of Motonui's industrial relations but provides a description of the managerial practices which have contributed to the project's outstanding industrial relations record.

\section{Method}

In depth interviews were conducted with 6 of Bechtel's senior management group including project, site and industrial relations managers. An additional 21 managerial staff completed questionnaires exploring management practice on the site. Interviews were also conducted with 4 full time union officials based in New Plymouth and involved on the project representing the Engineers, Labourers, Electrical Workers and Clerical Workers unions. Discussions were also held with Neville Taylor and Brian Evans who acted as combined union advocates on the site and with industrial mediator Jim Newman who handled most of the mediated disputes. The interview format was fairly unstructured, asking respondents to identify what they saw as the main reasons for the low levels of conflict at Motonui with areas of interest being further clarified as the interview progressed.

\section{General elements}

Content analysis of the interview data revealed a number of elements that contributed to industrial harmony on the project. Amongst these the role of the union leaders was critical. The union leaders both full-time and at delegate level were highly experienced. The combined union advocates Neville Taylor and Brian Evans for example, had had years of industrial experience and were regarded as highly effective negotiators. Several of the site delegates had acted as delegates for the same sub-contractors on the previous Kapuni ammonia/urea plant and Petralgas methanol plant projects. Industrial mediator Jim Newman, when asked to comment specifically on the experience of the union leaders, described them as "not only very experienced but also highly intelligent." This experience was supplemented by a training programme for delegates run (with the support of Bechtel) by Brian Evans, the combined union advocate.

The union leadership, particularly the full-time officials, were also committed to minimising the use of strike action in pursuing their claims. A number of these union leaders had experienced high levels of conflict on previous projects and were prepared to play their part in avoiding similar problems at Motonui. The following comments by union respondents are
illustrative:

We had a group of officials who were prepared to sit and talk before taking action. We exhausted every possible avenue, before strike action would be taken .

Our response was we would go out and discuss it .... we didn't use heavy antics. Probably because we were taking the best interests of the workers at heart. If it was a serious case we would do it ... but it was very seldom necessary to go out the gate on an issue.

Jim Newman made the following comments about union attitudes:

They adopted a let's fix it attitude. Let's identify the problem, and let's fix it. The union
attitude was to keep the blokes working.

This attitude, together with a substantial effort by the full time officials to maintain a presence on the site are clearly crucial elements in the industrial harmony that prevailed on the project. The close proximity of the project to New Plymouth also helped officials to maintain a 
level of involvement not possible on more isolated projects (see for example Turkington, 1976. p. 202).

Union attitudes on the Motonui project appear to have differed somewhat from those of the union leadership at Marsden Point. This paper makes no attempt to compare the "militancy" of the union leaders on the respective projects. It seems likely however that the willingness of the union leadership at Motonui to seek dispute resolution without recourse to strike action exceeded that of the union leaders involved on the Marsden Point project.

It is important to note that the wages and conditions negotiated for the workers on the site were very similar to those negotiated at Marsden Point. The interview respondents felt that the workers of Marsden Point had "one or two little things in advance" of those at Motonui, but that overall the pay and conditions were much the same. Some respondents expressed the view that the Motonui workforce came out on top overall because they experienced less down-time due to strikes.

Analysis of the 1982 Motonui and Marsden Point composite agreements lends support to the views of the interview respondents. Basic rates of pay appeared to be marginally higher overall at Motonui while the "job site construction allowance" at Marsden Point was higher at 235 cents an hour than the 202.3 cents negotiated at Motonui. Extra payments involving tool, height, welding etc allowances however were consistently (although marginally) higher at Motonui. Overall, the terms negotiated on the 2 projects appear to be fairly similar. The approach taken by the union leadership at Motonui clearly did not result in any significant differences in wages and conditions relative to those negotiated at Marsden Point. Their experience was sufficient to obtain good terms of employment for the workers on the site, and to guard against any attempts at manipulation on the part of Bechtel's managerial group.

Other parties also played an important role. Third party mediation was an important component in disputes resolution on the project. The efforts of Labour Department mediators, particularly Jim Newman from Wellington, in providing a quick resolution of disputes helped to maintain confidence in the project's disputes procedure.

A number of commentators have also pointed to the docility and inexperience of the Taranaki labour force, whom they claim were much less militant than, for example, the workforce at Marsden Point. Bechtel's management did not accept this view. They indicated that a substantial percentage of the workforce came from outside Taranaki, while the Taranaki workforce itself had demonstrated its potential for militancy on previous projects in the region.

The union officials interviewed were divided on this issue. Half felt that the "workforce was very lethargic" and that "the type of worker" had a lot to do with the low level of conflict on the project. The others did not see the nature of the workforce as being significant. While the exact influence of the nature of the workforce on the project's industrial relations is difficult to determine it seems unlikely to have been a major factor.

\section{The role of management}

The attitudes and experience of union officials and perhaps the nature of the workforce were positive factors in a construction project that retained a predisposition to conflict. The interview data indicate however that it was Bechtel's management approach that was the primary contributor to industrial harmony on the project. Bechtel were successful in managing industrial relations on the project in a way that harnessed the goodwill and experience of the union leadership and enabled most of the industrial relations problems to be resolved without work stoppages.

The following quote from one of the union officials highlights Bechtel's role:

the central point, the critical factor, was management. My observation generally is, if you get good management the industrial relations will be okay... we ve got no option. union work is reactive ... the main reason (for industrial harmony) was Bechtel and the system they set up.

Bechtel's industrial relations management approach is explored below.

\section{The managerial approach}

It is useful to conceive of Bechtel's approach at Motonui as falling into 2 broad categories. Initially they attempted to set up a broad framework which maximised their control over 
industrial relations on the project. Secondly, and within the context of that framework, they adopted managerial practices which minimised industrial relations problems, and handled those that did arise quickly and without the need for industrial action. These 2 approaches are examined below.

\section{Establishing a framework}

\section{(i) The approach to the unions}

In New Zealand the state has traditionally acted to stabilise industrial relations by establishing a framework of dispute resolution which presents alternatives to direct action (Walsh. 1979). In the periods when the legitimacy of that framework was accepted by the parties involved it proved to be an effective mechanism for stabilising the nation's industrial relations and minimising industrial stoppages. At Motonui, Bechtel were successful in establishing a framework which maximised the stability and predictability of the site's industrial relations. The framework involved a disputes procedure which like the state's conciliation and arbitration system presented alternatives to strike action. It also included other elements which may be seen as aspects of a broad strategy of managerial control. This framework is described below.

In New Zealand involvement of employees and particularly unions in the areas of managerial prerogative is minimal (McLennan et al., 1987; Smith, 1977). On the big projects management/union relationships tend to be conducted in an adversarial manner with managers seeking to maximise control by limiting the discretion of union leaders as much as possible. The management group at Motonui decided to approach the union situation in a different way. The key elements of their approach involved a view of the unions as an agency of control not disruption. The perspective taken was one which viewed conflict as flowing upward from the workforce and not as something generated by militant union officials.

The unions were seen in this context as organisations which, while not removing conflict, at least represented it in a coherent and predictable manner.

You cannot avoid a union situation, it's like deciding to do away with wheels, you are better off with them .... we tried to work to support the unions, to help the union officials do their job to help them keep control of the workforce. At Marsden Point and New Zealand Steel the workforce is too powerful for the unions.

This acceptance of the unions came as a surprise to some of the unionists:

I go to a lot of places ... it's a real battle to get employers to acknowledge we have got a role. At Motonui that was not an issue, I didn t even have to worry ... It was a refreshing change. They
felt there was a role to be played... I was accepted.

Pursuant to this strategy Bechtel dealt as much as possible with full-time union officials and supported them over the site delegates when disagreements occurred. They also discouraged the formation of a site committee which tends to transfer the power to the site delegates and removes responsibility and control from the full-time officials.

\section{(ii) Organisation structure and the use of sub-contractors}

The Marsden Point expansion project has been frequently criticised for its complex "spider's web" structure which hindered communication and slowed responses to union response By contrast Bechtel employed a simple matrix structure which permitted a rapid with the San Francisco head whilst retaining the depth and stability of a functional relationship

Bechtel sub-contracted work on the project as opposed to hiring the workforce direct. This presented some powerful advantages over the direct hire approach which for example, was with company loyalty. One established relationship between the conflict on the big projects emanates from the lack of an contracting appro submore easily controlled was seen as minimising this problem and dividing the workforce into more easily controlled units as the following management comments illustrate:

The unions here are extremely weak from a control point of view, not like in the USA or UK, if the union says go back to work the people go back... it can easily become anarchy. So one of the IR aspects was to try and break it up into a workforce that had a long-term loyalty to their company. More loyalty than say to a labour union .... a divide and conquer approach. 
The sub-contracting approach also simplified the actual management task and importantly placed Bechtel's management a step away from industrial problems. Rather than meeting the unions head-on in conflict situations they were able to adopt more of a third party mediation role.

One of the advantages of sub-contractor system is that you almost have a mediation role... it puts you on a step further away than direct hire. With the things we couldn't fix there was still somewhere else to go.

Bechtel's mediation role, particularly that of John Haslemore, the site's industrial relations manager was recognised by the union respondents:

Haslemore was in part a mediator. At times he had to go to his own management and say when in Rome do as the Romans do. Not only was he a manager of industrial relations, but he was an adviser as well. On a couple of occasions this applied to union officials as well.

\title{
Disputes resolution
}

The third arm of the framework established at Motonui involved the establishment of a highly effective disputes procedure. The system itself was extremely orthodox with the union raising the problem with the sub-contractor first. If it couldn't be resolved at that level Bechtel entered as a third party and attempted to help the 2 parties resolve the dispute. If Bechtel couldn t reach agreement with the union, then the decision was turned over to an industrial mediator. The procedure developed a high level of credibility with the unions as this statement from one of the full-time union officials illustrates:

I can t think of any union who didn't go through the disputes procedure. We knew if we went through the disputes procedure there was a 75 percent chance we would get it.

One of the main reasons for the high credibility of the disputes procedure was the rapidity with which Bechtel's industrial relations staff exercised their mediation role within it.

If the union was in dispute with the sub-contractor we usually heard from the delegate or employer. We would try and meet within the hour. If we couldn't agree we would call in a third party. We had a total commitment to resolve disputes quickly in an orderly controlled manner.

Bechtel's capacity to respond quickly to problems was also noted by the union officials:

\begin{abstract}
We were able to deal directly with Bechtel instead of pissing around with the subs.... there was one employer who would make a decision ... at Marsden no one was prepared to make a decision. they were scared of setting precedents. Down here no problems .... things were answered quickly. We wanted a yes or no, even if it was no at least we knew where we stood.
\end{abstract}

The attractiveness of the disputes procedure also related to the workload of the union officials. The project placed both full-time officials and site delegates under immense pressure. manifested for example by a high turnover of union leaders. The disputes procedure provided an attractive mechanism for resolving disputes in an orderly and time-effective manner.

With the disputes procedure in place and working well, Bechtel had established a key mechanism of control and stability. Their strategic position within the process also allowed them to control access to the procedure. This led directly to a greater level of control over the site's industrial relations.

With the system we set up both the union officials and the delegates became a little dependent on us...

One way of controlling the larrikin is to stop him using the system. You can cut access, tell him to piss off... If you use a mediation system it becomes very powerful ... you can't do that on a direct hire job.

Dispute resolution on the project was further facilitated by a network of meetings which drew all the parties together and allowed problems to be surfaced and dealt with quickly. 
Bechtel insisted that all the sub-contractors held weekly (Monday morning) "tool box" meetings to discuss safety issues. In practice, a variety of concerns were discussed in these tool box meetings. Bechtel staff reviewed the notes of these meetings and ensured that any concerns were dealt with. Unresolved issues, particularly concerning safety, could also be referred to monthly union/management safety meetings.

The safety meetings were supplemented by bi-monthly round-table meetings in which industrial relations staff met with union officials and site delegates to discuss problem areas. Additionally Bechtel agreed to monthly stop-work meetings ("Union Fridays") every third Friday of the month. The union officials encouraged the site delegates to use these meetings and they became another avenue through which problems surfaced.

These formal meetings were (as previously indicated) overlaid by an ongoing informal contact between urition leaders and Bechtel's industrial relations group. The combined result of an effective disputes procedure, and the formal and informal systems of communication operating on the site was that problems could be identified and dealt with quickly. Thus problems that carried the potential for high conflict could be resolved before they developed into major issues. The benefits of these systems of problem resolution are highlighted by the following statement from one of the union respondents:

At times you have to take some action to show the employer you mean business. But I can t think of any instances at Motonui. There was always some other alternative to taking
industrial action.

\section{Managerial practices on the project}

The following aspects emerged from the interview data as the most significant areas of management practice on the project.

\section{Detailed long range industrial relations planning}

The physical construction of the Motonui plant began in March 1982. The industrial relations planning started in 1980 . The key objective of this planning was to anticipate and if possible neutralise any potential causes of conflict.

We developed our IR strategy way before we got to New Zealand ...

We planned all the things that could go wrong, and developed all the things we could do to avoid them ... we worked hard to pull all the causes away... so in the end they only had stupid things to go on strike about.

The first contact was made with the union officials in June 1980.

We took 7 officials to San Francisco before the job started to talk and to listen, to talk about demarcation issues and to see the model. We also took them to a couple of jobs in Can-
ada.

Early discussions with the unions allowed demarcation issues to be identified and worked out before the project began.

Early involvement with the union officials also allowed the development of a site agreement which, in the words of a union official "dealt with every conceivable matter that could at that time be envisaged". The site agreement also provided a clause for matters not covered by the document. The planning also highlighted the benefits of a modular approach to construction in which large parts of the plant were preassembled out of New Zealand. This process reduced the number of tion time by allowing work to occur concurrently. Importantly, it also reduced the number of potential problems relating to demarcation and allowances for height,
confined space, dirt etc.

This approach to planning again represents a contrast to the Marsden Point expansion management approach. Some respondents claimed that the Marsden project's industrial relations plan was not even started until 2 months after construction had commenced. 


\section{Commitment by senior management to industrial relations}

Industrial relations was clearly considered an important issue from the start of the project. The industrial relations managers had a direct input at a high level and clearly had substantial influence on the management of the project. The following statement from Bechtel's project manager is illustrative: "We constantly considered labour relations ... and we relied on the judgment on the IR people... we leaned very much on the labour side". Another senior manager simply said "Industrial relations built Motonui".

The amount of discretion available to the industrial relations team greatly enhanced their credibility with the unions. Generally they were perceived as having a "lot of power" and being "able to make the decisions". The unions came to realise that they could deal with the site's industrial relations people and get a quick response which was not going to be vetoed by higher level management or by other interested parties such as the client. It appears that the industrial relations staff at Motonui enjoyed a level of power and involvement in senior management decision making which is unusual in the New Zealand construction industry.

\section{Close communication with union officials}

For both management and union respondents "close communication" between Bechtel and the union leadership was the most frequently cited reason for Motonui's low conflict levels. This communication was initiated by Bechtel in its first contacts with the union officials in 1980 and with the reciprocity of the unions became a key feature of the project's industrial relations. Communication was facilitated by the regular formal meetings discussed above and informally by an "open door" policy which provided union leaders with direct access to Bechtel's industrial relations managers. The following comments are from management and union officials respectively:

We made lots of effort to communicate, to listen. We maintained an open door policy. We would meet (the unions) at any time and listen.

It all came back to communication .... communication provided for an open door. It allowed the parties to talk and to resolve matters even out of document coverage ... it's the glaring lesson, communication is the name of the game.

The trust established through communication allowed an unusually co-operative and open approach to be used in negotiation between the parties. Again the following comments are from management and union officials respectively.

we told them in detail. (My superior) made by hair stand on end at first. He would give the delegates more information than the project managers... we talked openly about what our problems and risks were. We said here's my problem, instead of saying here's my position... we would say if we agree to this, this is what will happen in a month or so.

Why didn't we strike? Basically, because we decided if you play the ball game right we'll play it right too. They were always prepared to talk, the door was always open for discussion. Everyone was open. F... all back stabbing, if (they) said something (they) meant it.

\section{Safety issues}

Bechtel placed a strong emphasis on safety issues. During the project up to 4 experienced staff were employed on safety issues. Bechtel also insisted that each of the sub-contractors establish an effective safety meeting structure. Union leaders were closely involved and worked to keep issues of safety in high profile. The meeting structure ensured that safety issues surfaced and were resolved. Competitions were also held and prizes were given for good safety records. Overall the safety programme paid off. There were no fatalities on the project and a relatively low 1167 lost time accidents. The approach to safety benefited those working on the site and also minimised disputes over safety issues.

\section{Employment and training}

All employment on the site was directed through an employment office established by 
Bechtel in New Plymouth. This gave greater order to the employment process and stopped subcontractors competing for labour. This office also ensured that all of the new employees joined the appropriate union. Contacts were also maintained with other projects in New Zealand and overseas, to help redirect redundant workers into new jobs. This resulted in fewer disagreements over redundancy and helped maintain worker productivity towards the end of the project.

Critical skill shortages were handled by a series of training programmes established through the Taranaki Polytechnic. More than 1000 workers went through the various training programmes. The net result of the employment and training approach was a smoothing of the employment and redundancy process and a removal of potential conflict causes.

\title{
Managerial experience
}

All of the union officials interviewed identified the experience and competence of Bechtel's management group as being an important element in the project's successful industrial relations. The following statement from one of the union respondents is illustrative: "One of the major factors was that Bechtel had competent management far in excess of any employer Ive come across". This experience generated a number of benefits. At the planning and procurement level it meant there were few delays in materials and equipment, hence the workforce was seldom idle.

Both union and management respondents saw the experience of Bechtel's industrial relations managers in particular as being a critical element in the project's industrial relations. The following comments from a managerial respondent are illustrative:

\begin{abstract}
There's no doubt that you can't beat experience. (On some of the big projects) the IR people have never had the experience, they have never worked in this sort of work. We happen to have on this site a group of guys who have been through all the experiences. You can t beat having lived through a disaster.
\end{abstract}

John Haslemore's experience was seen by one union official as having a direct influence on communications. John Haslemore came from a wide background experience... because of his experience he's
not a smart alec. He's a bloody good communicator, he could talk to the workers and to his
own management.

The past experience of both the industrial relations and other senior managers on the project seemed also to have convinced them of the benefits of an approach to the unions which was more open and participative than is usual in New Zealand organisations. The questionnaire responses indicated a strong emphasis by the project managers on participation and communication. On the project the use of participation was genuine and far reaching as the following comments from a union official and senior manager illustrate:

\begin{abstract}
At every stage right down to the accommodation committee we had an input. It was right
from the top to the bottom.
We made a big effort to have the participation of the union to allow them to express their views and answer questions. Overall we developed an ability to discuss things and to reach a
consensus.
\end{abstract}

Importantly there was no naivety in this approach. It drew from a firmly pluralistic perspective and was consciously chosen as the best strategy to minimise conflict in a potentially difficult industrial environment. The use of participation was part of a highly sophisticated approach to the management of the site's industrial relations and operated in the context of meticulous long term planning and an experience-based understanding of the construction confrontational styles used elsewhere.

I think we were able to build up a high level of trust. In a lot of disputes you see people adopt a predictable approach based on aggression a hardline position. New Zealand IR managers generally take the wrong approach, an adversary role.... a lot look to confront more. 
The use of a participative approach at Motonui may therefore be viewed as part of a sophisticated strategy of control. It was an approach derived from experience, made possible by effective planning, and chosen as the most effective means of heading off conflict before it arrived at the point where an adversarial role became the only practical alternative. The approach was also reliant on the experience and co-operation of the union leaders. If the union officials had been less positive, industrial relations might have been managed differently. The following comment is from a management respondent:

Close communication was an optional extra. We could have decided tactically to do the job without them ... for example if the union officials are committed to killing the job we might go the other way, we could say we won't resolve disputes ...

On the Motonui project the end result as described by one of the union respondents was that "people were prepared to listen, to assist in training one another to the achievement of the ultimate goals of both parties".

\section{Conclusion}

The Motonui methanol plant project provides a good example of the effective management of industrial relations on a major project. Interviews conducted with managers and union officials involved, indicate that the Bechtel management group combined experience with intensive planning to develop a framework and an approach to industrial relations that contributed significantly to industrial harmony on the project. The experience and attitudes of the union officials involved were also of major significance in the success of the project. Ultimately however Bechtel's management group, in particular their industrial relations managers, must take the primary credit for establishing a system which maintained the involvement of union officials and resolved problems without significant work stoppages.

While recognising the limitations of what is primarily a descriptive study, it is argued that the Motonui experience contains lessons for those managing industrial relations elsewhere. It is argued that effective management can reduce the level of industrial conflict even in industries that are predisposed to conflict. Managers operating in organisations with bad industrial relations records would do well to review their own industrial relations performance before abrogating their responsibility to factors and agencies beyond their control. For its part the academic community could do much more to research and to teach approaches to industrial relations management which can be effective in reducing conflict. In the final analysis it is the managers who shape the patterns of conflict in their organisations.

The Motonui experience indicates that in the management of industrial relations, New Zealand managers can significantly improve their performance.

\section{References}

Cammock, P A (1983) Media reportage of an industrial dispute Unpublished paper towards MCom degree, University of Auckland.

Clegg, S (1979) The theory of power and organisations London, Routledge and Kegan Paul.

Cordery, J, Jamieson, B and Stacey, B (1978) Industrial relations as news New Zealand journal of industrial relations $3(2)$ : 57-62.

Edwards, P K and Scullion, H (1982) The social organisation of industrial conflict Oxford, Blackwell.

Hartman, P (1976) Industrial relations in the news media Industrial relations journal 6(4) : 4-18.

Howells, J M, Woods, N S and Young, J F L (Eds) (1974) Labour and industrial relations in New Zealand Australia, Pitman Books.

Inkson, J H K (1980) New Zealand's troubled meat industry Employee relations 2(1) : 11-16. Jackson, M P (1978) Industrial relations London, Croom Helm. 


\section{0}

Peter Cammock

McLennan, R. Inkson, J H K Dakin, S R Dewe, P and Elkin, G (1987) People and enterprises in press.

Niland, J and Turner, D (1985) Control, consensus or chaos? In Managers and industrial relations reform Sydney, Allen and Unwin.

Storey, J (1983) Managerial prerogative and the question of control London. Routledge and Kegan Paul.

Smith, D F (1979) Developments in worker participation in New Zealand Industrial relations journal 21(1) : 35-50.

Turkington, D J (1976) Industrial conflict Wellington. Methuen.

Walsh. P (1979) The giant wakes up Industrial relations review 1(4) : 12-16. 